
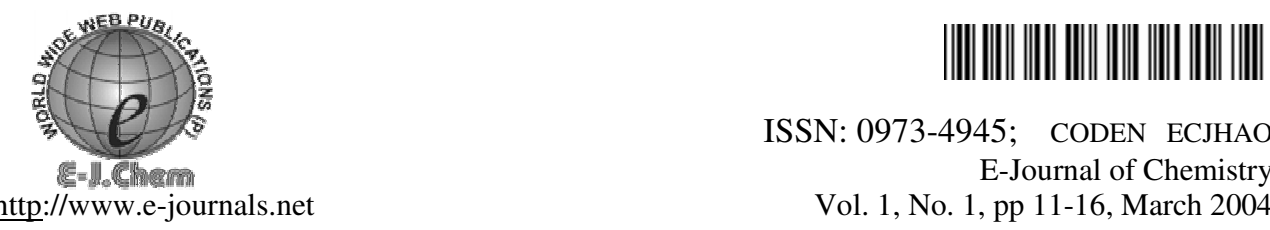

ISSN: 0973-4945; CODEN ECJHAO

E-Journal of Chemistry

Vol. 1, No. 1, pp 11-16, March 2004

\title{
Modified Castor Oil as an Epoxy Resin Curing Agent
}

\author{
B.P.PATEL*, H.S.PATEL and S.R.PATEL \\ Department of Chemistry, \\ S.P.University, Vallabh \\ Vidyanagar - 388 120, Gujarat (INDIA)
}

Received 13 February 2004; Accepted 26 February 2004

\begin{abstract}
A castor oil, an agricultural product, is an unsaturated material. Hence the castor oil is brominated by bromine liquid. The brominated castor oil (BCO) was then reacted with excess of aliphatic diamines viz; ethylene diamine, 1,3propane diamine and 1,6-hexane diamine. The resultant amino functionalized castor oil (ACO) samples were then characterized by elemental analysis, IR spectral study and number of amino groups. All the three ACO samples were then employed for the curing of commercial Brominated epoxy resin. The curing of epoxy resin by ACO was monitored on differential scanning calorimeter (DSC) and based on the DSC study their glass fibre reinforced composites (GRC) were fabricated. The cured samples (i.e. unreinforced) were also subjected to thermo gravimetric analysis (TGA). The chemical, mechanical and electrical properties of the glass fibre reinforced composites (GRC) were also evaluated.
\end{abstract}

Keywords: Brominated epoxy resin, Brominated castor oil, Amino functionalized castor oil, TGA, GRC

\section{Introduction}

Castor oil is derived from bean of the castor plant (Recinus communis) belonging to the family of Euphorbiaceac1. It is a mixture of triglyceride fatty acids. The unique characteristic of this oil is that it contents approximately $90 \%$ of ricinoleic acid. Ricinoleic acid has 18- carbon on its backbone with one Hydroxyl group on the $12^{\text {th }}$ carbon atoms and it also has a cis double bond between the $9^{\text {th }}$ and $10^{\text {th }}$ carbon atoms. The structure of the castor oil is shown in Scheme 1.

Several reviews covering agronomics marketing, processing and application aspects of this oil ${ }^{1-6}$ have already appeared. Castor oil is mostly used in the form of its modified derivatives such as dehydrated, hydrogenated, alkoxylated, sulphated and the halogenated derivatives $^{1-6}$. 
Being alkyl halogenated type system present in brominated castor oil (BCO), the nucleophilic substitution reaction of $\mathrm{BCO}$ could exist. The area in which the reaction of BCO with diamine has not received attention academically and technically. This can afford an amine functionalised castor oil, which could be used as an epoxy resin hardener. Hence it was thought interesting to study the amino functionalised castor oil-epoxy resin curing system. The present paper comprises the bromination of castor oil, reaction of BCO with aliphatic diamines, characterization, DSC monitoring of amino functionalized castor oil epoxy resin systems and glass reinforcement of such systems. The research work is scanned in scheme 1.

\section{Experimental}

\section{Materials}

Castor oil was obtained from local market. Its hydroxyl value and number of hydroxyl groups were estimated using an acetylating method as described in the literature ${ }^{8}$.

Castor oil triglyceride of recenoleic acid

Hydroxyl value 156 .

$-\mathrm{OH}=2.24$ per mole of castor oil.

The Aliphatic diamines used are

1. Ethylene diamine

2. 1,3-propane diamine.

3. 1,6-hexane diamine.

These diamines were purchased from Diamines chemicals, Nandesari.

The epoxy resin was obtained from Synpol Products ltd, Ahmedabad.

The specification of the Brominated epoxy resin are as follows.

- $\quad$ Epoxy equivalent weight is 230 ,

- $\quad$ Viscosity is $800 \mathrm{cps}$ at $75^{\circ} \mathrm{C}$.

The glass fibre used for composites fabrication was purchased from Unnati Chemicals, Ahmedabad.

The glass fibre used was of E- type glass cloth plain weave and epoxy compatible.

All other chemicals used were of laboratory grade.

Synthesis of bromo derivative of castor oil

The bromination of castor oil was carried out by the reported method in literature ${ }^{7}$. The method is as follows. To a solution of $83.5 \mathrm{gm}(0.1 \mathrm{~mole})$ Castor oil in $350 \mathrm{~mL}$ carbon tetrachloride $\left(\mathrm{CCl}_{4}\right)$, a solution of $45.5 \mathrm{~g} \mathrm{Br}_{2}(0.28 \mathrm{~mole})$ in $75 \mathrm{~mL}$ carbon tetrachloride was added drop wise over a period of half an hour. The reaction temperature was maintained at $20^{\circ} \mathrm{C}$ during the whole period of reaction. The quantity of the bromine added was in excess of the calculated theoretical amount. On completion of reaction, the amount of bromine left unreacted in the reaction mixture was reduced by using $5 \%$ aq. sodium sulphite solution. The aqueous layer was then separated from organic layer, which contained the desired product. Anhydrous sodium sulphate was then added and the solvent was distilled off under vacuum. The resulting brominated castor oil was designated as BCO.

\section{Reaction of $B C O$ with aliphatic diamides}

A solution of aliphatic diamine (listed in Table 1) in ethanol, was gradually added to a solution of $\mathrm{BCO}$ in ethanol with stirring at room temperature, The saturated sodium bicarbonate solution was added as an acid acceptor. The reaction was kept aside till gas 
ceases. The resulting brown pasty mass was washed by ethanol and then by dry ether. Finally it was air-dried the resulted amino functionalised caster oil samples were designated as ACOs (3a-c).

Table 1. Characterization of modified castor oil

\begin{tabular}{|c|c|c|c|c|c|c|}
\hline \multirow{2}{*}{ Samples } & \multirow{2}{*}{$\begin{array}{l}\text { Molecular } \\
\text { formula }\end{array}$} & \multirow{2}{*}{$\begin{array}{l}\text { Molecular } \\
\text { weight }\end{array}$} & \multicolumn{4}{|c|}{$\begin{array}{l}\text { Elemental Analysis Found } \\
{ }^{*} \mathrm{Cal} \text { (Found) }\end{array}$} \\
\hline & & & $\% \mathrm{C}$ & $\% \mathrm{H}$ & $\% \mathrm{~N}$ & $\% \mathrm{O}$ \\
\hline \multirow{2}{*}{1} & & & 32.39 & 59.09 & - & 5.11 \\
\hline & $\mathrm{C}_{57} \mathrm{H}_{104} \mathrm{O}_{9} \mathrm{Br}_{6}$ & 1412 & $(32.37)$ & $(59.08)$ & - & $(5.10)$ \\
\hline \multirow{2}{*}{$3 a$} & & & 29.24 & 61.86 & 5.08 & 3.41 \\
\hline & $\mathrm{C}_{69} \mathrm{H}_{146} \mathrm{~N}_{12} \mathrm{O}_{9}$ & 1286 & $(29.22)$ & $(61.85)$ & $(5.07)$ & $(3.79)$ \\
\hline \multirow{2}{*}{$3 b$} & & & 29.52 & 62.20 & 4.72 & 3.54 \\
\hline & $\mathrm{C}_{75} \mathrm{H}_{158} \mathrm{~N}_{12} \mathrm{O}_{9}$ & 1370 & $(29.50)$ & (62.19) & $(4.70)$ & $(3.52)$ \\
\hline $3 c$ & $\mathrm{C}_{93} \mathrm{H}_{194} \mathrm{~N}_{12} \mathrm{O}_{9}$ & 1622 & $\begin{array}{l}30.19 \\
(30.15\end{array}$ & $\begin{array}{r}62.98 \\
(62.96) \\
\end{array}$ & $\begin{array}{r}3.89 \\
(3.87) \\
\end{array}$ & $\begin{array}{c}2.92 \\
(2.90)\end{array}$ \\
\hline
\end{tabular}

* Indicates values are based on chemical structure.

\section{Composite fabrication}

The Composites were prepared by using glass fibre. The glass fibre resin ratio is 60:40 by weight. suspension of epoxy resin and various ACOs in desired amount and 2-2-3 drops of pyridine were prepared on a weight basis and stirred well for 5 minutes. The suspension was then applied to a $15 \mathrm{~cm}$ X $15 \mathrm{~cm}$ glass fibre. The 10 prepreges were stacked on top of one another and pressed between steel plates coated with a Teflon film released sheet and compressed in flat platen under 70psi pressure. This prepregs stack was cured after keeping it in an autoclave oven maintained at their respective curing temperature for about 6 hours. The composites so obtained were cooled to $50^{\circ} \mathrm{C}$ before the pressure was released. The composites were then machined to final dimensions.

\section{Measurements}

The $\mathrm{C}, \mathrm{H}$, and $\mathrm{N}$ contents of all the three ACOs were estimated by means of a Carlo Erba Elemental Analyzer (Italy). The data are included in Table 1. The $\mathrm{NH}_{2}$ determination was carried out by titriometric method as nonaqueous conductometric titration. Formic acid acetic acid mixture was used as solvent and standard perchloric acid in formic acid- acetic acid mixture was used as titrand. The IR spectra were taken using a Nicolet Impact $400 \mathrm{D}$ Spectro photometer.

\section{Curing}

Curing of epoxy resin was carried out by differential scanning calorimeter. A Du Pont 900 DSC was used for this study. The instrument was calibrated using standard indium metal with known heats of fusion $(\wedge \mathrm{H}=28.45 \mathrm{~J} / \mathrm{g})$. Curing was carried out from $30-300^{\circ} \mathrm{C}$ at $10^{\circ} \mathrm{C}$ $\mathrm{min}^{-1}$ heating rate. The sample weight for this investigation was in the range of $4-5 \mathrm{mg}$, and an empty cell was used as a reference. The DSC thermograms data are furnished in Table 2. Unreinforced cured samples were subjected to thermo gravimetric analysis on Du Pont 950 thermo gravimetric analyzer in air at a heating rate of $10^{0} \mathrm{C} \mathrm{min}{ }^{-1}$ The TGA data is furnished in Table 3. 
Table 2. DSC curing of epoxy resin

\begin{tabular}{ccccc}
\hline \multirow{2}{*}{ Sample } & \multicolumn{3}{c}{ Curing temp. $\left(\mathrm{T}^{0} \mathrm{C}\right)$} & \multicolumn{1}{c}{$\begin{array}{c}\text { Activation Energy } \\
(\text { Ea })\end{array}$} \\
\cline { 2 - 5 } & $\mathrm{T}_{\mathrm{k}}$ & $\mathrm{T}_{\mathrm{p}}$ & $\mathrm{T}_{\mathrm{f}}$ & $\mathrm{J} / \mathrm{g}$ \\
\hline $3 \mathrm{a}$ & $119^{\circ} \mathrm{C}$ & $126^{\circ} \mathrm{C}$ & $145^{\circ} \mathrm{C}$ & 37.24 \\
$3 \mathrm{~b}$ & $113^{\circ} \mathrm{C}$ & $122^{\circ} \mathrm{C}$ & $140^{\circ} \mathrm{C}$ & 30.01 \\
$3 \mathrm{c}$ & $105^{\circ} \mathrm{C}$ & $117^{\circ} \mathrm{C}$ & $135^{\circ} \mathrm{C}$ & 10.74 \\
\hline
\end{tabular}

Table 3. TGA of unreinforced cured samples of epoxy resin

\begin{tabular}{cccccc}
\hline & \multicolumn{5}{c}{ \% Weight Loss at various } \\
\cline { 2 - 6 } Sample & 300 & 400 & 500 & 600 & 700 \\
\cline { 2 - 6 } & 0.4 & 10.71 & 68.09 & 75.50 & 83.01 \\
\hline $3 \mathrm{a}$ & 0.3 & 09.80 & 67.90 & 75.01 & 82.60 \\
$3 \mathrm{~b}$ & 0.2 & 09.02 & 67.01 & 74.02 & 81.80 \\
\hline
\end{tabular}

\section{Composite Characterization}

\section{Chemical resistance test}

The resistance against chemicals of the composite samples was measured according to ASTM D 543.

\section{Mechanical testing}

All mechanical testings were performed using three test specimens.

- $\quad$ The compressive strength was measured according to ASTM D 695.

- $\quad$ Impact strength was measured using Izod type impact tester at

- $\quad$ Room temperature, according to method of ASTM D 256.

- $\quad$ The Rockwell hardness was measured according to ASTM D 785.

\section{Electrical testing}

Measurement of the dielectric strength was carried out on a high voltage tester machine oil test set.

\section{Results and Discussion}

The brominated castor oil was synthesized by the reported procedure ${ }^{7}$. The amination reaction of $\mathrm{BCO}$ with various diamines was carried out by simple condensation reaction. The excess diamine was used to get ACO with more and more amino groups. $\mathrm{N}$ content and $\mathrm{NH}_{2}$ group determination characterized the ACO. The $\mathrm{NH}_{2}$ determination was carried out by titriometric method as nonaqueous conductometric titration. Formic acid- acetic acid mixture was used as solvent and standard perchloric acid in formic acid- acetic acid was 
used as titrant. The result of $\mathrm{NH}_{2}$ group of all the ACO indicates that, around $6 \mathrm{NH}_{2}$ groups were present per mole of the ACO. The inspection of the IR spectra of ACO reveals that, all the IR spectra all most resemble to castor oil. Only the descerimible difference is that the spectrum of ACO comprises the new bond at $3400,3300 \mathrm{~cm}^{-1}$ due to presence of $\mathrm{NH}_{2}$ groups.

As the ACO containing $\mathrm{NH}_{2}$ group, the ACO were tried for curing of BER for this commercial BER was purchased with epoxy group about 2. i.e. Brominated epoxy resin the ACO- BER system was monitored on the DSC . From the DSC thermograms of all the systems, the kickoff fro (Tk), the peak temprarute (Tp) and final temp $\left(\mathrm{T}_{\mathrm{f}}\right)$ were noted and furnished in Table 2. The calculation of kinetic parameters is also given in Table 2.

The ACO- BER cured product was also analyzed for TGA. The TGA data of all cured products are present in Table 3. Chemical, Mechanical and electrical properties of glass reinforced composites of epoxy resin are shown in Table 4. The results show that the cured product starts the degradation in the range of $280-790^{\circ} \mathrm{C}$ depending upon the nature of the polymer. The degradation is rapid after the temp $400^{\circ} \mathrm{C}$. All the product loss completely at the temperature about $850^{\circ} \mathrm{C}$. The Glass Fibre reinforced composites (GRC) of ACO- series were also prepared based on DSC data. The laminates have good chemical resistivity. The strength of laminates is also quite good. Thus so called ACO could be ranked as good curing agent for epoxy.

Table 4. Chemical, mechanical and electrical properties of glass reinforced composites of epoxy resin

\begin{tabular}{|c|c|c|c|c|c|c|}
\hline \multirow{2}{*}{ Sample } & \multicolumn{2}{|c|}{$\begin{array}{c}\text { Chemical resistance } \\
\% \text { change in }\end{array}$} & \multirow{2}{*}{$\begin{array}{l}\text { Impact } \\
\text { Strength } \mathrm{MPa}\end{array}$} & \multirow{2}{*}{\multicolumn{2}{|c|}{$\begin{array}{l}\text { Compressive Rockwell } \\
\text { strength, MPa Hardness (R) }\end{array}$}} & \multirow{2}{*}{$\begin{array}{l}\text { Electrical } \\
\text { strength in } \\
\text { air, } \mathrm{kV} / \mathrm{mm}\end{array}$} \\
\hline & Thickness & Weight & & & & \\
\hline $3 a$ & 1.1 & 1.2 & 348 & 371 & 111 & 18.8 \\
\hline $3 b$ & 1.0 & 1.1 & 352 & 360 & 106 & 20.1 \\
\hline $3 c$ & 1.2 & 1.4 & 365 & 341 & 104 & 20.9 \\
\hline
\end{tabular}

Acknowledgement

The authors are grateful to Prof. Dr. R. M. Patel, Head Dept. of chemistry for providing the necessary research facilities.

\section{References}

1. Annual Book of ASTM Standards, Pt 29, D960-73, Washington, D. C. 1976, precipitation 525 .

2. Lakshminarayana G, Paulose M M, Shripathi Rao H, Vishwanadham B, Laxminarayana J and Ramalingaswami P A, Project Costs for Hydrogenation and Dehydration, res. Ind,1988, 33, 9.

3. Lower E S, Hydrogenated Castor oil, Riv Ital Sostanze Grasse, 1993, 70, 87. Chem Abstr, 1993, 119, 162779.

4. Tomoyuki I, Jurairattana D, Piyasan P and Sanguan S, The effect of palladium on Activity and Selectivity of Nickel catalyst in Hydrogenation of Castor Oil, Kenkyu Hokoku-asahi Garasu Zaidan, 1990, 56, 65. 
5. Schwitzer M K, Perspectives and Prospects of the World Castor oil Industry, Oleogineux, 1983, 38, 253.

6. Turner R B, Chem Rev 1948, 43, 271.

7. Elham A A and Yousef, ahmed. Ed; Hussain and Zein Ed; Shoeb, J Sci and Industrial Research 2001, 60.383.

8. Vogel A I, Quantitative Analysis Part III. longmans, London, 1957. 


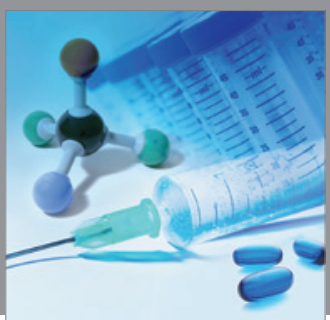

International Journal of

Medicinal Chemistry

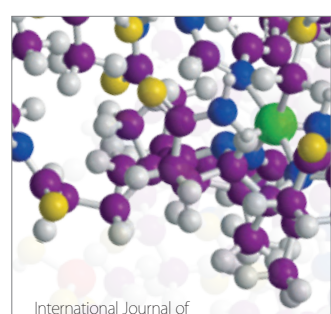

Carbohydrate Chemistry

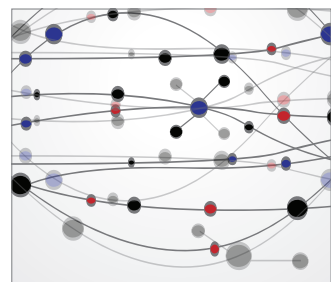

The Scientific World Journal
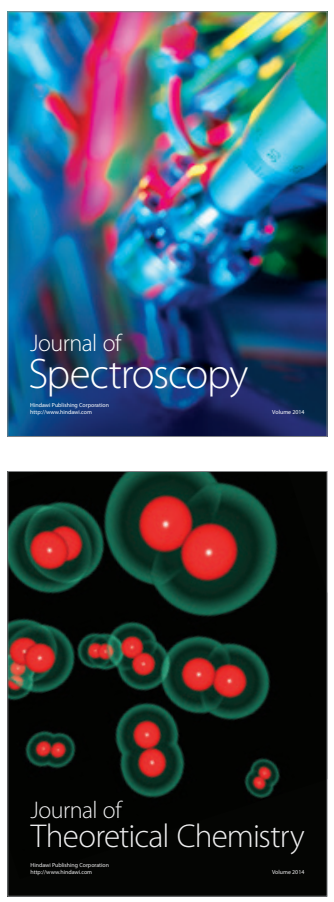
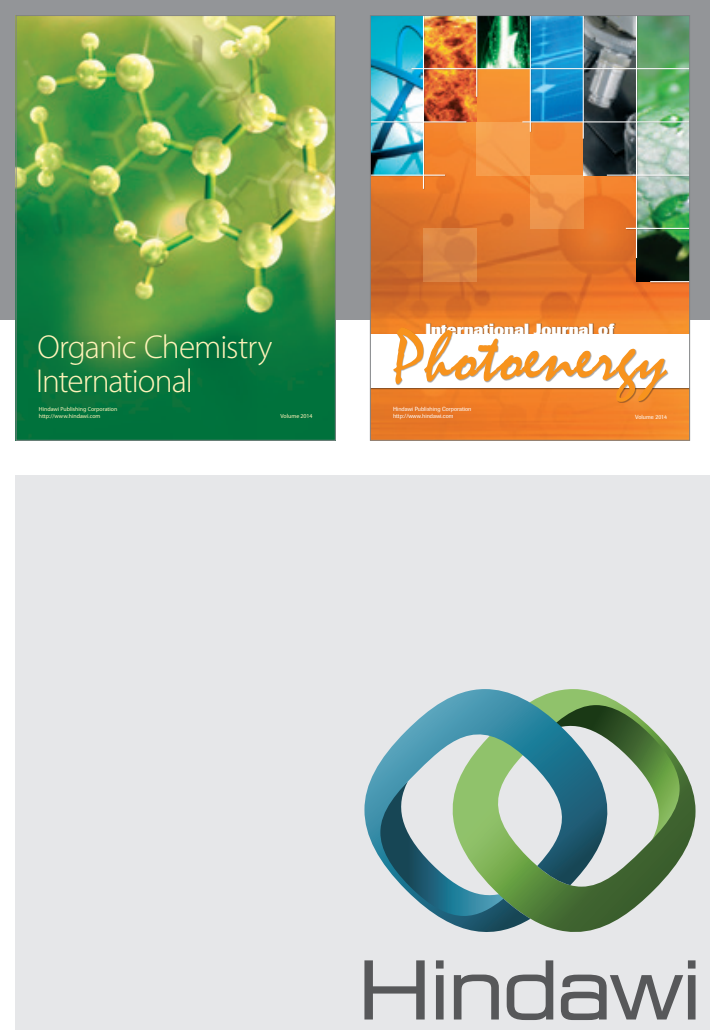

Submit your manuscripts at

http://www.hindawi.com
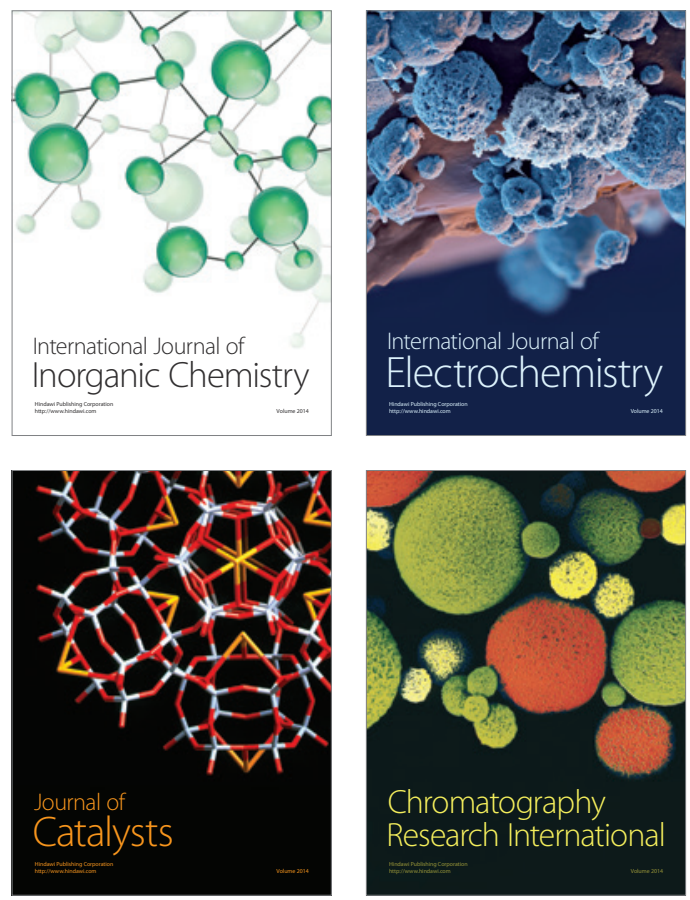
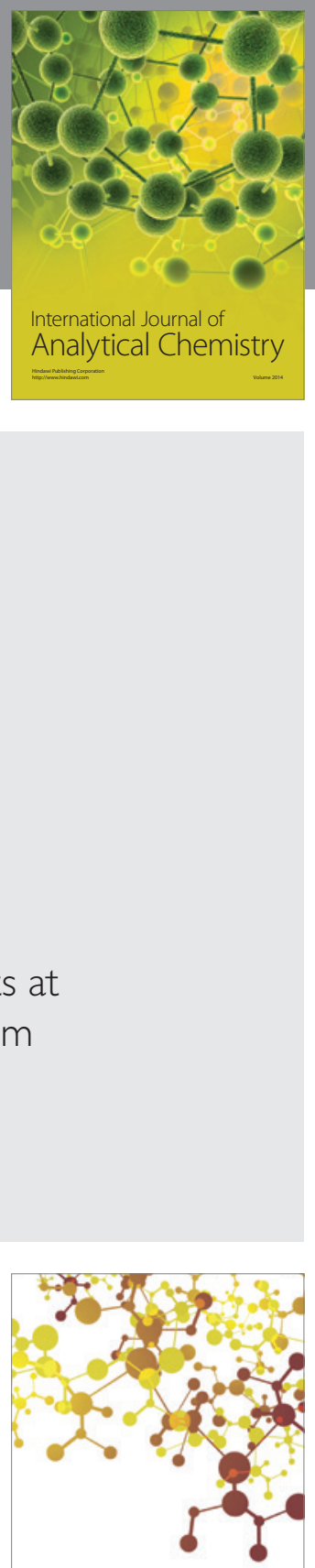

Journal of

Applied Chemistry
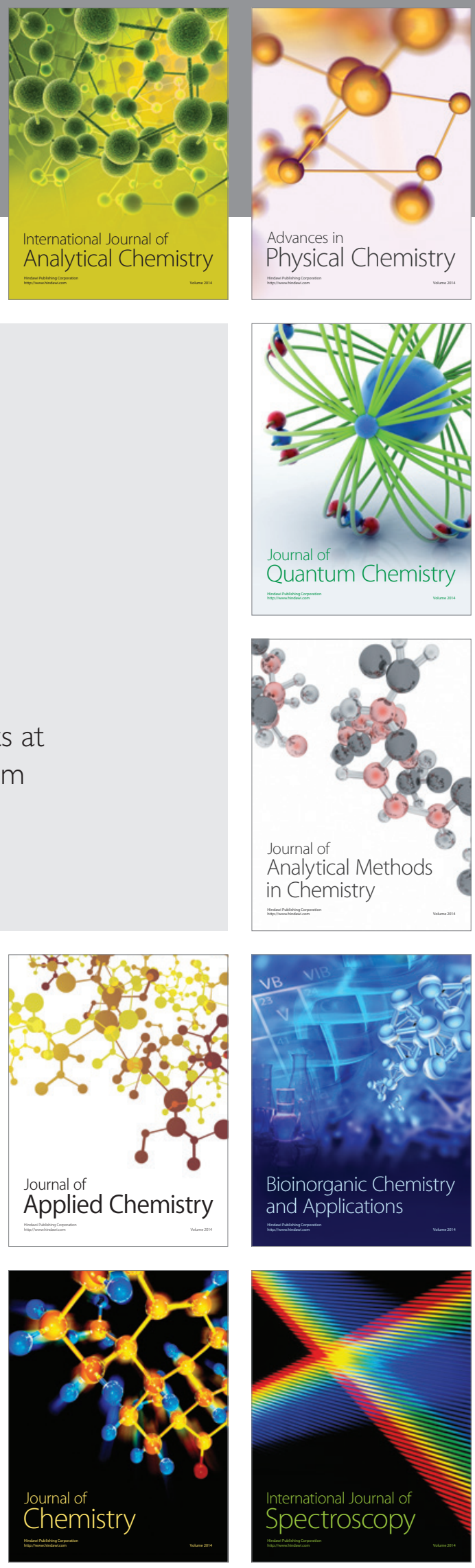